УДК 656.078:338.48

JEL Classification L 91, M 11, R 40

DOI 10.31375/2226-1915-2020-1-71-85

$$
\begin{array}{r}
\text { Н.В. Ярова } \\
\text { к.е.н., доцент, } \\
\text { доцент кафедри «Економіка і фінанси» } \\
\text { ORCID: 0000-0002-9703-3305 } \\
\text { О.В. Воркунова } \\
\text { к.е.н., доцент, } \\
\text { доцент кафедри «Економіка і фінанси» } \\
\text { ORСID: 0000-0003-2451-5853 } \\
\text { К.О. Коцюбенко } \\
\text { Вспірантка кафедри «Економіка і фінанси» } \\
\text { В.Сіщенко } \\
\text { аспірант кафедри «Економіка і фінанси» } \\
\text { Одеський національний морський університет, } \\
\text { Одеса, Украӥна } \\
\text { МВАННЯ МЕТОДИЧНИХ ПОЛОЖЕНЬ } \\
\text { ЕННЯ КОНКУРЕНТОСПРОМОЖНОСТІ } \\
\text { «ТС-КОНТЕЙНЕРНИЙ» }
\end{array}
$$

ФОРМУВАННЯ МЕТОДИЧНИХ ПОЛОЖЕНЬ ПІДВИЩЕННЯ КОНКУРЕНТОСПРОМОЖНОСТІ КОНТЕЙНЕРНОГО ТЕРМІНАЛУ НА ПРИКЛАДІ

Анотація. У статті розглянуті різноманітні підходи, методи до оцінки конкурентоспроможності підприємства, які базуються на різних кониептуальних засадах.

Розвиток України як транзитної держави обумовлюе необхідність ефективного розвитку послуг з обробки вантажів та їх ивидкої поставки до місия призначення. Через зростаючу конкурениію на ринку підприємств морського транспорту підвищення ефективності діяльності вітчи зняних МТП можливе лише за умови за без-печення власних конкурентних переваг. Вирімення иієї зада чі вимагає комплексного підходу до розв'язання проблеми підвищення конкурентоспроможності.

У результаті проведеного аналізу існуючих методів оиінки конкурентоспроможності підприємств у статті було запропоновано організаиійну модель підвищення конкурентних позииій та переформування "ТIC-Контейнерний» в "Хаб Порт» для залучення транзитних вантажів $і$ подальшу відправку плавзасобами меншого класу чи наземним видом транспорту, використовуючи розвинене автомобільне сполучення $i$ залізнодорожні иляхи. ТІС має всі необхідні ресурси для такого масштабного реформування своєї діяльності.

Також застосування запропонованої методики на практиці дозволяє визначити суб'єктивну оцінку конкурентоспроможності кожної послуги і віднайти слабкі місия.

Для оцінки конкурентоспроможності послуг ТІС були розроблені методичні положення, які базуються на розрахунку комплексного показника, який відображає особливості обробки вантажів включає обтрунтовані за результатами дослідження фактори конкурентоспроможності.

Ключові слова: конкурентоспроможність підприємства, методи, підходи, підприємства морського транспорту.
УДК 656.078:338.48

JEL Classification L 91, M 11, R 40

DOI 10.31375/2226-1915-2020-1-71-85

$$
\begin{array}{r}
\text { Н.В. Яровая } \\
\text { к.Э.н., доцент, } \\
\text { доцент кафедры «Экономика и финансы» } \\
\text { О.В. Воркунова } \\
\text { к.э.н., доцент, } \\
\text { доцент кафедры «Экономика и финансы» } \\
\text { Е.А. Коцюбенко } \\
\text { аспирантка кафедры «Экономика и финансы» } \\
\text { В.С. Лищенко } \\
\text { аспирант кафедры «Экономика и финансы» } \\
\text { Одесский национальный морской университет, } \\
\text { Одесса, Украина }
\end{array}
$$

ФОРМИРОВАНИЕ МЕТОДИЧЕСКИХ ПОЛОЖЕНИЙ ПОВЫШЕНИЯ КОНКУРЕНТОСПОСОБНОСТИ КОНТЕЙНЕРНОГО ТЕРМИНАЛА

НА ПРИМЕРЕ«ТИС-КОНТЕЙНЕРНЫЙ»

Аннотация. В статье рассмотрень различные подходы, методы к оценке конкурентоспособности предприятия, основанные на различных концептуальных основах.

Развитие Украинь как транзитного государства обусловливает необходимость эффективного развития услуг по обработке грузов и их быстрой поставки к месту назначения. Из-за растущей конкуренции на рынке предприятий морского транспорта повышение эффективности деятельности отечественных МТП возможно лишь при условии обеспечения собственных конкурентных преимуществ. Решение этой задачи требует комплексного подхода к решению проблемы повымения конкурентоспособности.

В результате проведенного анализа существуюших методов оченки конкурентоспособности предприятий, в статье была предложена организациионая модель повышения конкурентных позиций u переформирования «ТИС-Контейнерный» в «Хаб Порт» для привлечения транзитных грузов и последуюшую отправку плавсредствами меньшего класса или наземным видом транспорта, используя развитое автомобильное сообщение и железнодорожные пути. ТИС имеет все необходимые ресурсы для такого масштабного реформирования своей деятельности.

Также применение предложенной методики на практике позволяет определить субъективную оценку конкурентоспособности каждой услуги и найти слабые места.

Для оченки конкурентоспособности услуг ТИС были разработаны методические положения, основанные на расчете комплексного показателя, который отражает особенности обработки грузов и включает обоснованные по результатам исследования факторы конкурентоспособности.

Ключевые слова: конкурентоспособность предприятия, методы, подходы, предприятия морского транспорта.

() Яровая Н.В., Воркунова О.В., Коцюбенко К.О., Ліщенко В.С., 2020 
UDC 656.078:338.48

JEL Classification L 91, M 11, R 40

DOI 10.31375/2226-1915-2020-71-85

N.V. Yarova

Candidate of Economic Sciences, Associate Professor, Associate Professor of the Department «Economics and Finance» ninayarova2017@gmail.com

ORCID ID: 0000-0002-9703-3305

O.V. Vorkunova

Candidate of Economic Sciences, Associate Professor, Associate Professor of the Department «Economics and Finance» i.ramazanov@gmail.com ORCID ID: 0000-0003-2451-5853

K.O. Kotsiubenko

$\mathrm{PhD}$ student of the Department «Economics and Finance» katerina.kotsyubenko@gmail.com

V.S. Lishchenko

$\mathrm{PhD}$ student of the Department «Economics and Finance» grand2.0@meta.ua

Odessa National Maritime University, Odessa, Ukraine

\section{FORMATION OF METHODOLOGICAL PROVISIONS OF INCREASING THE COMPETITIVENESS OF THE EXAMPLE TIS-CONTAINER CONTAINER TERMINAL}

Abstract. The article considers various approaches, methods for assessing the competitiveness of an enterprise, based on various conceptual foundations.

Sea Trade Ports of Ukraine operate under market conditions and ever-increasing competition, both among themselves and from ports of neighboring countries. This necessitates a corresponding revision of the theoretical and applied provisions in the field of management of the development of the material and technical base of the ports. First of all, it is connected with research and development of theoretical and methodical propositions. Their implementation will provide adequate modern conditions of management, decision-making aimed at improving the competitiveness of the Sea Trade Ports.

Due to the fact that the concept of competitiveness is multifaceted, it includes different aspects of the enterprise activity, information about which is not always quantitative but more often descriptive, most methods of determining competitiveness have different restrictions on their use, due to different approaches. to evaluation, using different indicators that characterize the competitiveness of the enterprise, lack of available information, so the result can have a significant error, and am the process of determining the competitiveness of enterprises be time consuming.

The development of Ukraine as a transit state necessitates the effective development of services for the processing of goods and their quick delivery to their destination. Due to growing competition in the market of maritime transport enterprises, an increase in the efficiency of domestic ICCs is possible only if their own competitive advantages are ensured. Solving this problem requires an integrated approach to solving the problem of increasing competitiveness.

As a result of the analysis of existing methods for assessing the competitiveness of enterprises, the article proposed an organizational model for enhancing competitive positions and 
transforming TIS-Container into HubPort to attract transit cargo and then sending it by craft of a smaller class or by land using a developed automobile connection and railways. TIS has all the necessary resources for such a large-scale reform of its activities.

Also, the application of the proposed methodology in practice allows us to determine the subjective assessment of the competitiveness of each service and find weaknesses.

To assess the competitiveness of TIS services, methodological provisions have been developed based on the calculation of a comprehensive indicator that reflects the features of cargo handling and includes competitive factors based on the results of the study.

Keywords: enterprise competitiveness, methods, approaches, maritime transport enterprises.

Постановка проблеми. Морські торговельні порти (МТП) України працюють в умовах ринку і постійно зростаючої конкуренції, як між собою, так і з боку портів сусідніх країн. Це обумовлює необхідність відповідного перегляду теоретичних і прикладних положень в галузі управління розвитком матеріально-технічної бази портів. Перш за все, це пов'язано $з$ дослідженням і розробкою теоретичних і методичних положень. Їх реалізація забезпечить адекватне сучасним умовам господарювання, прийняття рішень, спрямованих на підвищення конкурентоспроможності МТП [10].

Разом 3 різноманітністю визначень поняття «конкурентоспроможність підприємства» в теорії і практиці пропонуються й різноманітні підходи до іiі оцінки, що висвітлювались y працях зарубіжних і вітчизняних вчених.

Внаслідок того, що поняття конкурентоспроможності $€$ багатоскладним, таке, що включає в собі різні сторони діяльності підприємства, інформація про яку не завжди має кількісне значення, а частіше має описовий характер, більшість методів визначення конкурентоспроможності мають різні обмеження щодо їх використовування, що обумовлено різними підходами до оцінки, викори- станням різних показників, що характеризують конкурентоспроможність підприємства, відсутністю наявної інформації, тому отриманий результат може мати значну похибку, а сам процес визначення конкурентоспроможності підприємства може бути трудомістким. Деякі вчені до системи оціночних показників одночасно включають показники конкурентоспроможності підприємства і конкурентостійкості підприємства. Оскільки ці терміни характеризують підприємство в статиці і в динаміці, результати оцінки конкурентоспроможності і конкурентостійкості підприємства мають різну область застосування, то підхід до оцінки повинен це враховувати.

Огляд останніх досліджень і публікацій. Здатність підприємства вести суперництво на внутрішньому та світових ринках отримала втілення в категорії «конкурентоспроможність».

Більшість фахівців абсолютно вірно визначають природу кризи у вітчизняному портовому господарстві $\mathrm{i}$, насамперед, пов'язують їх 3 моральним і фізичним зносом портового обладнання, а також занадто високими тарифами на портові послуги. Проте шукають вихід 3 неї або у державно-приватному партнерстві чи, навіть, приватизації портів або у 
більш активному державному втручанні з метою зменшення тарифів. В той самий час ринковим механізмам збільшення конкурентоспроможності вітчизняних портів, у тому числі за рахунок нецінових чинників, все ще приділяється недостатньо уваги.

Теоретичні і практичні аспекти підвищення конкурентоспроможності вітчизняних морських портів розглядаються в роботах вітчизняних $\mathrm{i}$ закордонних науковців таких, як Боняр С.М., Дергачов B.О., Котлубай А.І., Могалевкін І.М., Чекаловець B.I. та інших [8-10]. Також окремі питання конкурентних переваг у морегосподарському комплексі висвітлюються у працях Омельчук С.С., Олефір I.М, Примачова М.Т., Столярова Г.П. $[1 ; 7 ; 10]$.

Проте, до теперішнього часу питання щодо визначення теоретичних аспектів конкурентоспроможності підприємства та факторів, що на неї впливають, ще недостатньо вивчені і вимагають більш поглибленого дослідження.

У сучасних умовах підприємства морського транспорту вимушені самостійно вирішувати ці завдання, кінцеві результати їх діяльності багато в чому залежать від того, наскільки об'єктивно ними оцінюється рівень попиту в різних сегментах світового ринку перевезень.

Мета дослідження. Метою статті $€$ підвищення конкурентних позицій та переформування «TICКонтейнерний» в «ХабПорт» для залучення транзитних вантажів і послідуючу відправку плавзасобами меншого класу чи наземним видом транспорту, використовуючи розвинене автомобільне сполучення і залізнодорожні шляхи.
Основний матеріал дослідження. Проведений аналіз літератури показав, що існують наступні основні підходи, методи до оцінки конкурентоспроможності підприємства, які базуються на різних концептуальних засадах: аналізу конкуренції в галузі, стратегічного аналізу макрооточення, діагностики конкурентного середовища, параметричних оцінок, індексний, ієрархій, рейтингових оцінок, інтегрального показника, оцінки за конкурентоспроможністю товару, інтегрального показника, методи оцінки, які побудовані за теорією ефективної конкуренції, оцінки за теорією ефективної конкуренції, загального показника конкурентоспроможності, що базується на задоволенні споживача та ефективності виробництва, оцінки за нормою прибутку, оцінки за вартістю бізнесу, метод, в основі яких лежать принципи порівняльних переваг [5].

Слід зазначити, що однакові найменування методів оцінки рівня конкурентоспроможності підприємства зовсім не означають, що ці методи ідентичні. Такі методи здебільше $є$ різними, хоча і спостерігаються співпадіння у принципах оцінки. Проведемо аналіз деяких 3 вищеназваних методів. Метод оцінки конкурентоспроможності підприємства на основі теорії порівняльних переваг застосовується тоді, коли необхідно одержати статичну оцінку становища підприємства на ринку без аналізу його майбутніх дій в умовах зовнішнього середовища, що змінюються, а також коли розглядається питання про доцільність розширення масштабів виробництва.

Підприємство може забезпечити собі міцний конкурентний ста- 
тус шляхом наявності порівняльних переваг, які виражаються в нижчих витратах виробництва в порівнянні 3 конкурентами. Це $є$ лише характеристикою ефективності виробництва i його масштабу, але не відображає ефективності діяльності підприємства на ринку і його взаємодії із покупцями продукції, що ним вироблюється. Тому при оцінці конкурентоспроможності цим методом разом із витратами виробництва застосовуються як база порівняння такі показники як обсяг виробництва і норма прибутку, обсяг продажів, частка ринку, рентабельність виробництва. При цьому вищий рівень показника одного підприємства вважається достатнім для висновку про те, що воно більш конкурентоспроможне.

Проте, такий підхід оцінки конкурентоспроможності підприємства, грунтуючись на масштабі функціонування підприємства, не відображає рівень конкурентоспроможності його продукції, а ефективність виробничогосподарської діяльності не може характеризуватися тільки рентабельністю, оскільки іiі тимчасове зниження часто може сприяти підвищенню конкурентоспроможності підприємства у зв'язку із спрямуванням засобів на розширення ринку збуту і упровадження нововведень для ефективного виробництва в майбутньому.

Метод оцінки конкурентоспроможності підприємства на підставі теорії якості товару припускає, що основним критерієм конкурентної переваги підприємства є споживча цінність виробленої ним продукції. Висновок про ступінь конкурентоспроможності виробника здійснюється на підставі зіставлення характеристик продукції свого підприємства і про- дукції конкурентів із ідеальними i найкращими значеннями на ринку i визначаються бажані вимоги до характеристик своєї продукції із урахуванням їх впливу на зміну рентабельності виробництва і збуту.

Методом оцінки конкурентоспроможності підприємства, що базується на визначенні ефективності виробничо-господарської діяльності i конкурентоспроможності продукції, $\epsilon$ метод, що грунтується на теорії ефективної конкуренції. Зіставляються підприємства-конкуренти за наступними показниками: ефективність виробничо-збутової діяльності, ефективність виробничої діяльності, а також за показниками фінансової стійкості підприємства. При цьому порівняння проводиться не тільки за одиничними і груповими показниками діяльності конкурентів, але i iз середньогалузевими показниками.

Аналогічний підхід до формування показників запропоновано в роботі Г.А. Іващенко. Оцінка факторів формування конкурентоспроможності підприємства проводилася за узагальнюючими таксономічними показниками рівня розвитку: ефективність виробничої діяльності; ефективність фінансової діяльності; ефективність управління персоналом; ефективність інноваційної діяльності; ефективність маркетингової діяльності [2].

Такий підхід містить більш повний склад узагальнюючих показників, але не враховує динаміки чинників, що впливають на рівень конкурентоспроможності підприємства.

Одним 3 методів оцінки рівня конкурентоспроможності є метод, заснований на положеннях теорії мультиплікаторів. Механізм мультиплі- 
кації стосовно оцінки рівня конкурентоспроможності: підприємство для підтримки високого рівня конкурентоспроможності повинне постійно здійснювати інвестиції в розвиток свого стратегічного потенціалу, а також в заходи, пов'язані з адаптацією до умов, які формуються детермінантами «національного ромба» М.Е. Портера. Ефект від цих інвестицій тим вище, чим вище якість задоволення потреб покупців, а в перспективі тим вищі доходи підприємства, його прибуток. Проте, ефекти залежать від їх стимулів послідовно. Тому зниження впливу одного із стимулів може порушити весь подальший ланцюжок ефектів.

Результати методу оцінки конкурентоспроможності підприємства, що базується на теорії рівноваги підприємства і галузі, мають умовний характер, оскільки на практиці в світовій економіці досконалої конкуренції не існує, а галузі в результаті свого розвитку ніколи не перейдуть в стан рівноваги. Тому такий метод існує, але практично не використовується, а в період перехідної економіки його взагалі застосовувати недоцільно.

До методів оцінки конкурентоспроможності також відноситься метод кількісного аналізу на основі розрахунку інтегрального показника. На конкурентоспроможність підприємства впливає велика кількість чинників. Конкурентоспроможним виявляється те підприємство, товар якого задовольняє потреби покупця оптимальним чином, і виробництво цього товару $є$ найефективнішим. Такий метод передбачає аналіз не одного виду продукції, а всього асортименту продукції, що випускається, тому вима- гає об'ємних розрахунків по різних наборах як технічних, так і економічних характеристик продукції, 3 метою їх зіставлення і порівняння із нормативними параметрами. Інтегральний метод передбачає комплексний підхід до оцінки конкурентоспроможності підприємства є і достатньо наглядним засобом, що дозволяє одержати однозначні оцінки конкурентних позицій підприємства. На практиці він найчастіше застосовний, тому що враховує в рівній мірі як оцінку конкурентоспроможності продукції, так і ефективність виробничо-господарської діяльності підприємства, характеризує реальні умови функціонування підприємства.

У методиці, яка запропонована I. Зулькарнаєвим та Л. Ільясовою в роботі пропонується модель конкурентоспроможності підприємства, яка виявляє залежність частки ринку та іiі динаміки, що виступають зовнішніми факторами конкурентоспроможності, від ресурсів підприємства. В роботі не наведено перелік показників, які характеризували би використання ресурсів підприємства, але аналізуючи наведений в роботі приклад зрозуміло, що величина ринкової частки залежить від дії таких вагоміших факторів: продуктивність праці (характеризує одночасно рівень кадрового $\mathrm{i}$ виробничого менеджменту), залишкова вартість основних засобів (характеризує матеріально-технічний ресурс), фінансовий менеджмент, що обумовлює рентабельність власного капіталу. 3 нашої точки зору, до переваг методу І. Зулькарнаєва та Л. Ільясової можна віднести математично обгрунтований вибір форми інтегрального показника та об'єктивна оцінка вагових коефіцієнтів, що надає мож- 
ливості менеджерам докладати зусилля в окремих напрямках діяльності відповідно до їхньої вагомості. Також $\epsilon$ слушним тезис авторів, що будьякий розрахунковий показник роботи підприємства $€$ характеристикою потенціалу, який може бути як реалізованим, так і ні. Тому при оцінці стратегічної конкурентоспроможності має бути врахована конкурентостійкість підприємства. Неточним, на наш погляд, є розгляд авторами понять «конкурентоспроможність підприємства» та «частка ринку» як рівнозначних [1; $5 ; 9 ; 10]$.

У роботі $\mathrm{X}$. Фасхієва для оцінки рівня конкурентоспроможності підприємства запропоновано сімдесят сім показників, які згруповані у шість груп [11]:

- показники фінансово-господарської діяльності;

- виробничі показники;

- показники якості продукції;

- показники розвитку;

- показники рівня персоналу та соціальної сфери;

- показники рівня досконалості управління.

Слід відмітити, що з одного боку, враховано принцип комплексності при оцінці конкурентоспроможності підприємства, і велика кількість показників дає змогу точніше іiі оцінити; з іншого боку - більшість 3 цих показників вимагає для розрахунку закритої інформації, а також існуе ризик дублювання показників.

В методиці, яка запропонована К. Щиборщем, для оцінки якості функціонування групи підприємств було використано десятифакторну модель, в основу якої закладено дві структурні компоненти - ефективність господарської діяльності і фі- нансова стабільність. Показники першої групи, до яких віднесено - чотири показники рентабельності та показник ступеню зносу основних засобів, характеризують довгострокову ефективність підприємства. Показники другої групи - три коефіцієнти ліквідності, показник оборотності оборотного капіталу та частка власних коштів у сукупних пасивах підприємства, зумовлюють поточну фінансову стабільність підприємства.

Широко поширені матричні методи оцінки конкурентоспроможності підприємства. Для аналізу конкурентних позицій підприємства можна використовувати широко відомі і часто використовувані в зарубіжній практиці моделі. Матриця Бостонської консалтингової групи (BCG) [2] $\epsilon$ своєрідним відображенням позицій конкретного виду діяльності в стратегічному просторі, що визначуються двома координатними осями. Одна 3 них використовується для відображення темпів зростання галузі, а інша - для відображення контрольованої відносної частки продукції на ринку.

Даний метод можна використовувати для одного або групи однорідних товарів. В цьому випадку найбільш конкурентоспроможним буде товар, або група однорідних товарів, що займає значну частку на ринку, що швидко зростає. Недоліком методу $\epsilon$ неможливість проведення аналізу причин того, що відбувається, і ускладнює процес прийняття управлінських рішень.

Модель «Привабливість ринку - переваги в конкуренції» $є$ розвитком описаної вище моделі. Матриця дозволяє визначити положення даного товару (підприємства) на рин- 
ку відносно інших конкурентів, а також дозволяє виробити стратегічні рекомендації по поліпшенню рівня конкурентоспроможності товару (підприємства). Слід відзначити, що визначення чинників моделі вимагає великої кількості інформації, яка найчастіше буває недоступна. Модель статична і відображає тільки заданий проміжок часу.

Матриця Портера побудована на основі концепції конкурентної стратегії: у центрі уваги підприємства не тільки задоволення потреб покупців, але і конкуруючі сили ринку. Така концепція передбачає наявність особливої позиції по відношенню до конкурентів, але невідомі способи досягнення цих позицій. В концепції не враховано швидкі зміни ринкових умов.

Матричні методи можна застосовувати для оцінки конкурентоспроможності підприємства на різних стадіях життєвого циклу його товару і технології. Проте, експертна оцінка рівня показників за двох - або трьохбальною шкалою (високий, середній i низький рівень) без виділення значущості показників робить підхід надмірно спрощеним.

При комплексному дослідженні економічної системи за параметрами, які визначають ऑiі майбутній стан застосовуються такі прикладні прийоми i методи: STEP-аналіз, SWOT-аналіз, SPACE-аналіз, GAPаналіз, метод аналізу LOTS, PIMSаналіз, модель GE/McKinsey.

На нашу думку, слід більш уважно підійти до підбору показників; формування груп показників. Показники конкурентоспроможності і конкурентостійкості підприємства слід враховувати окремо.
Як видно 3 вищерозглянутих методів і підходів оцінки конкурентоспроможності підприємства серед вчених не існує єдиної узгодженої думки як за кінцевим результатом такої оцінки, інформаційною базою, способом оцінки i використання іiі результатів.

Таким чином, проведений аналіз літератури дозволяє зробити такі висновки. Важливою проблемою при оцінці конкурентоспроможності підприємства, продукції $є$ дефіцит інформації. Внаслідок закритості фінансової і іншої інформації, що відноситься до «комерційної таємниці», методи, що засновано на кількісних оцінках мають обмеження щодо використання. 3 одного боку, ця проблема може бути вирішена шляхом аналізу фінансової звітності, з іншого, конкурентоспроможність - це складна комплексна характеристика, яка охоплює різні сторони діяльності підприємства, тому до складу показників можуть входити і такі, що потрібно оцінювати тільки за допомогою експертів. Тому доцільним $є$ використання методів, що базуються як на кількісних параметрах, так і на експертних оцінках.

У науковій та періодичній літературі часто можна зустріти такі поняття як «хаб» (hub), «порт-хаб» (hub port), логістичний хаб (logis-tics hub), «Перевалочний порт» (transshipment port), «сухий порт» (dry port), «морський термінал» (maritime terminal), «розподільний центр» (distribution centre). Разом 3 тим універсального визначення поняття «порт-хаб» (hub port) немає.

Термінологія охоплює великий спектр понять, багато авторів вкладають сенс в поняття «порт-хаб» 
в такі синоніми як «вузловий порт» або просто «хаб».

Виникнення поняття «портхаб» в морській логістиці зобов'язане просторовій моделі «хаб-енд-спок» (hub \& spoke), що отримала поширення в авіаційній галузі США в кінці 1970-х.

Тригером практичного викорис-
1978 р. в США Акту про дерегулювання авіаційної галузі. В результаті дії цього закону у американських авіакомпаній з'явилася можливість самостійно встановлювати тарифи за переліт і формувати маршрутну мережу. Крім того були знижені вхідні бар'єри в галузь цивільної авіації нових компаній (рис. 1). тання моделі стало прийняття в

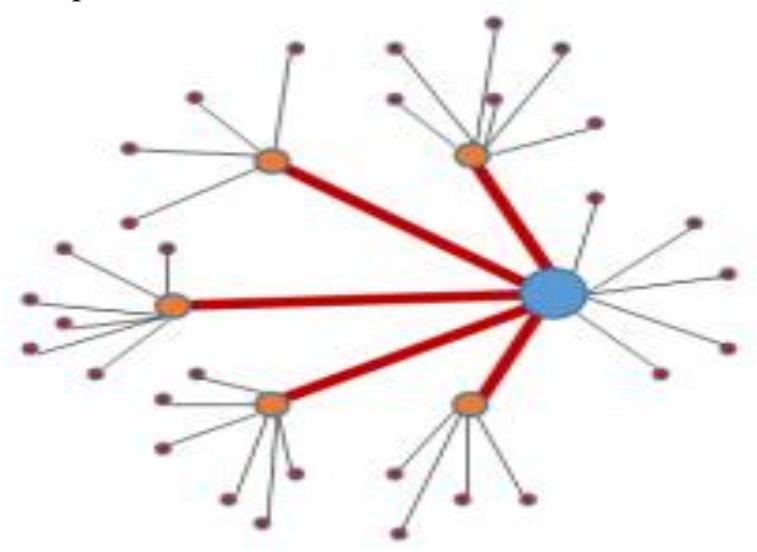

Рис. 1. Модель «хаб-енд-спок»

Джерело: розробка авторів [2; 11]

Поява в середині 1970-х моделі «хаб-енд-спок» значно змінило як регіональні, так і глобальні ланцюжки поставок. Від самого початку використана в авіаційній галузі система швидко отримала поширення і в інших видах транспорту. У морському транспорті, на частку якого припадає 90 \% загального обсягу перевезень в міжнародній торгівлі, поява моделі «хаб-енд-спок» ознаменувало новий етап розвитку портів. У морській логістиці, міжрегіональним вузлом, консолідуючим транспортні потоки, став саме порт-хаб.

Неоднорідність використання терміна «порт-хаб» пояснюється іноземним походженням словосполучення. Разом 3 тим єдності у визначенні терміна серед зарубіжних дослідників також немає.

Більшість західних дослідників (Т. Ноттебум, А. Баїрд, К. Фагерхолт, Е. Гай, Р. Маккал) розуміють під портом-хабом вузловий портовий комплекс, в операційній діяльності якого превалює операція транспшіпмента контейнерних вантажів. дослідники виділяють три форми трансшипменту $[2 ; 5 ; 9]$ :

- «Хаб-енд-спок» (hub \& spoke). Метою порту хаба $є$ забезпечення зв'язку між фідерними і океанськими судами, зв'язок регіональних і глобальних транспортних мереж. Порт виступає як місце консолідації вантажних потоків за рахунок свого центрального (найбільш дос- 
тупного) місця в регіоні. Вантажопідйомність океанських і фідерних судів значно відрізняється, так як фідерні судна обслуговують відносно невеликі вантажні партії і використовуються для перевезень по морю;

- «Проміжна ланка» (interlining). При даній формі трансшипменту порт-хаб виступає як місце можливої перевалки вантажу при довгих морських маршрутах. Вантажопідйомність суден перевалки приблизно однакова;

- «Перетин» (relay). Порт-хаб формується на місці перетину декількох довгих морських маршрутів лінійних перевізників. Вантажопідйомність суден перевалки приблизно однакова.

По суті, такі форми трансшипменту як «проміжна ланка» (Interlining) i перетин (relay) виступають модифікаціями віялової структури маршрутів типу хаб-енд-спок (hub \& spo-ke), що сформувалася в авіаційній галузі.

Порт-хаб (hub port) - великий контейнерний порт, обладнаний для швидкої перевалки вантажів 3 метою зменшення сталійного часу. Являється логістичним центром, в який надходять партії вантажів 3 подальшим розподілом по місцях їх призначення на березі, або по більш дрібним портам. Статус порту-хаба гарантуе великий обсяг вантажопотоку і розвиток відповідних логістичних сервісів. Тож не дивно, що стати хабом, означає зайняти найвигіднішу конкурентну позицію поміж підприємств морської діяльності [9].

У літературі і в практичній діяльності зустрічаються рішення, пов'язані з удосконаленням окремих напрямків виробничої діяльності порту.
Разом 3 тим не враховується взаємодія порту з конкурентами і необхідність підтримувати i підвищувати конкурентоспроможність, яка повинна відповідати новим тенденціям глобалізації світової торгівлі і виробництва. Це обумовлює необхідність розробки концептуальної моделі формування програми розвитку «TICКонтейнерний», спрямованої на підвищення конкурентоспроможності як окремих підрозділів (терміналів), так і порту в цілому.

Одним 3 ключових питань в моделі формування програми розвитку порту є дослідження сукупності об'єктів і факторів, що безпосередньо впливають на можливість порту залучати й обслуговувати своїх клієнтів. У ході цього дослідження:

- розробляється прогноз величини обсягів вантажопотоків, як для держави в цілому, так і для окремих регіонів;

- проводиться аналіз конкуренції, який включає в себе вивчення правового поля, рівнів, а також сил визначають конкуренцію;

- виконується оцінка конкурентоспроможності для розглянутих морських торговельних портів-конкурентів.

Розглянуте комплексне дослідження дозволить на початковому етапі запобігти значних фінансових втрат від помилкових рішень про реалізацію пропонованих ініціаторами проектів шляхом своєчасного виявлення їх неспроможності. Крім того, можуть бути визначені подальші напрямки розвитку ТIC 3 урахуванням впливу конкурентів, всебічного аналізу кон'юнктури ринку і оцінки відповідності його виробничої діяльності вимогам клієнтів. Можливі параметри 
для оцінки конкурентоспроможності послуг порту можуть бути поділені:

1. Нормативні (міжнародні запитання, державні запитання).

2. Технічні (параметри призначення, технологічні параметри).

3. Економічні (вартість послуг, додаткові витрати).

4. Організаційні (система знижок, умови платежів, комплексність послуг).

Одним 3 методів оцінки конкурентоспроможності товарів і послуг $€$ розрахунок інтегрального показника конкурентоспроможності $[2 ; 5 ; 7]$.

Розрахунок інтегрального показника конкурентоспроможності здійснюється за формулою

$$
K=\frac{I_{m n}}{I_{э n}},
$$

де $K$ - інтегральний показник конкурентоспроможності аналізованої послуги по відношенню до послугизразка.

За змістом показник $K$ відображає розходження між порівнює послугою в споживчому ефекті, що припадає на одиницю витрат покупця з придбання та споживання послуги.

Розрахунок групового показника за такими параметрами як технічні, організаційні, нормативні здійснюється за формулою

$$
I_{m n}=\sum_{i=1}^{n} k_{i}^{p} \cdot a_{i},
$$

де Imn - груповий показник конкурентоспроможності за технічними (організаційним, нормативним) параметрами;

kip - одиничний показник конкурентоспроможності по і-му технічному (організаційному, нормативному) параметру, який розраховується за формулою (3). $a i$ - вагомість і-го параметра в загальному наборі $3 \mathrm{n}$ технічних (організаційних, нормативних) параметрів, що характеризують потребу;

$n$ - число параметрів, що беруть участь в оцінці.

Розрахунок одиничного показника конкурентоспроможності проводиться за формулою:

$$
\text { варіант А. При } q_{i}^{p} \rightarrow \max
$$

$$
k_{i}^{p}=\frac{q_{i}^{p}}{q_{i o}^{p}},
$$

$(i=1,2,3, \ldots, n)$,

де $k_{i}^{p}$ - одиничний показник конкурентоспроможності по і-му технічному параметру;

$$
q_{i}^{p} \text { - величина і-го параметра для }
$$
аналізованої послуги;

$q_{i o}^{p}$ - величина і-го параметра для виробу, прийнятого за основу (вибирається найкращий за величиною для кожного параметра).

Варіант Б. При $q_{i}^{p} \rightarrow \min$ розраховується зворотна величина.

Розрахунок групового показника за економічними параметрами проводиться за формулою

$$
I_{e n}=\frac{3}{3_{0}},
$$

де Ien - груповий показник за економічними параметрами;

$3,3_{0}$ - повні витрати споживача відповідно по оцінюваній послузі і зразку.

Результати оцінки конкурентоспроможності послуг $є$ складовими частинами методу оцінки конкурентоспроможності порту як підприємства в цілому 
DEVELOPMENT OF MANAGEMENT AND ENTREPRENEURSHIP METHODS ON TRANSPORT, № 1 (70), 2020
РОЗВИТОК МЕТОДІВ

УПРАВЛІННЯ ТА ГОСПОДАРЮВАННЯ

НА ТРАНСПОРТІ, № 1 (70), 2020

$$
K_{\kappa n}=i_{e n} E_{n}+i_{\Phi n} \Phi_{n}+i_{e \mu} E_{M}+i_{K y l} K_{y l}
$$

В основі цього методу лежить оцінка чотирьох групових показників або критеріїв конкурентоспроможності [2]:

1. Ефективність виробничої діяльності порту (En);

2. Фінансове становище порту $(\Phi n)$

3. Ефективність організації маркетингу $(E M)$;

4. Конкурентоспроможність послуг (Ky).

Основним показником конкурентоспроможності морського торговельного порту являється вантажопотік і кількість опрацьованого вантажу. Для цього потрібні великі площі, налагоджена робота обслуговуючого персоналу, розвинена транспортна система i iнфраструктура порту.

TIC - найбільший портовий оператор в Україні за показниками вантажообігу.

До групи TIC входять п'ять спеціалізованих терміналів і власне TIC, який забезпечує функціонування залізничної та іншої інфраструктури. TIC володіє і управляє всією обслуговуючою інфраструктурою терміналів, в тому числі власною залізничною станцією.

TIC-Контейнерний термінал глибоководний термінал, довжиною 16 м в країні 3 найдовшим причалом, який складає 470 м. Це дозволяє приймати судна типу Post-Panamax, які не може прийняти жоден інший порт в Україні [4].

«ТІС-Контейнерний» термінал оперує на причалах № 21 і № 22 в акваторії порту Південний. Основною послугою стивідорних операторів являється надання послуг вантажовласникам 3 опрацювання їхнього вантажу з мінімальним строком і високою якістю. Для підтвердження високої якості послуг терміналу «ТІCКонтейнерний», розрахуємо інтегральний показник конкурентоспроможності, керуючись початковими даними стосовно надання послуги HРP причальними перевантажувачами. Дані представлені у таблиці 1.

Характеристики причальних перевантажсувачів

\begin{tabular}{|l|c|c|c|c|}
\hline \multicolumn{1}{|c|}{ Характеристика } & $\begin{array}{c}\text { Од. ви- } \\
\text { міру }\end{array}$ & $\begin{array}{c}\text { ДП «Чорноморсь- } \\
\text { кий морський тор- } \\
\text { говельний порт» }\end{array}$ & $\begin{array}{c}\text { ДП «Одеський } \\
\text { морський торго- } \\
\text { вельний порт» }\end{array}$ & $\begin{array}{c}\text { ТІС - Контей- } \\
\text { нерний }\end{array}$ \\
\hline Вантажопідйомність & тонн & 45 & 40 & 50 \\
\hline $\begin{array}{l}\text { Швидкість обробки } \\
\text { ТЕU }\end{array}$ & с & 62 & 54 & 45 \\
\hline Надійність & $\%$ & 84 & 90 & 90 \\
\hline Вартість & тис./дол. & 1700000,0 & 1800000,0 & 1970000,0 \\
\hline
\end{tabular}

Джерело: розробка авторів з використанням [4; 8; 10]

Розрахунок інтегрального показника звели в табл. 2. 
Таблиия 2

Розрахунок інтегрального показника

\begin{tabular}{|l|c|c|c|}
\hline \multicolumn{1}{|c|}{ Порт } & $\begin{array}{c}\text { Технічні } \\
\text { характеристики }\end{array}$ & $\begin{array}{c}\text { Економічні } \\
\text { характеристики }\end{array}$ & $\begin{array}{c}\text { Інтегральний } \\
\text { показник }\end{array}$ \\
\hline $\begin{array}{l}\text { ДП «Чорноморський } \\
\text { морський торговельний } \\
\text { порт» }\end{array}$ & 0,81 & 1,00 & 0,81 \\
\hline $\begin{array}{l}\text { ДП «Одеський морський } \\
\text { торговельний порт» }\end{array}$ & 0,87 & 0,94 & 0,82 \\
\hline ТІС - Контейнерний & 1 & 0,86 & 0,86 \\
\hline
\end{tabular}

Джерело: розробка авторів [4; 8; 10]

Таким чином, найбільш конкурентоспроможною за технічним і економічним показником $є$ послуга стивідорного оператора «ТIC-Контейнерний». Конкурентоспроможність цього підприємства за технічними показниками становить - 1 , це конкурентоспроможність «ідеального» виробу - кращого за всіма показниками.

За економічними характеристиками інтегральний показник складає 0,86 . Загалом це становить 0,86 від «ідеального». Найменш конкурентоспроможною є послуга ДП «Чорноморський морський торговельний порт».

Досягнути такого рівня підприємству «ТІС-Контейнерний» вдалося завдяки найсучаснішому обладнанню для ринку України.

Висновки. 3 вищевикладеного матеріалу можна зробити висновок про те, що застосування запропонованої методики на практиці дозволяе визначити суб'єктивну оцінку конкурентоспроможності кожної послуги і віднайти слабкі місця. Отримана модель залежності використання обладнання і фондів від параметрів конкурентоспроможності, може використовуватись підприємствами для прогнозування доцільності проекту і його вагомості при моделюванні впливу змін на майбутні результати діяльності.

\section{СПИСОК ЛІТЕРАТУРИ}

1. Воркунова О.В., Хотєєва Н.В., Маковейчук К.В., Павіліаніті-Карпова К.С. Фактори формування ефективної системи економічної безпеки підприємств морської галузі: зб. наук. пр. Дніпропетровський наи. універ. залізничного транспорту ім. акад. В. Лазаряна «Проблеми економіки транспорту». Вип. 13. Дніпро: Дніпропетр, 2017. С. 47-53.

2. Купріенко С.В. Формування програми розвитку матеріально-технічної бази морського торгового порту: автореф. дис. канд. техн. наук: 05.22.01. Одеса, 2008. $22 \mathrm{c}$. 
3. Онисько С.М., Марич П.М. Фінанси підприємств: підручник для студентів вищих навчальних закладів освіти. Львів: Магнолія Плюс, 2005. 428 с.

4. Офімійний веб-сайт Державноӥ служби статистики. URL: http:// ukrstat.gov.ual

5. Пономаренко В.С., Тридід О.М., Кизим М.О. Стратегія розвитку підприємства в умовах кризи: монографія. Харків: ІНЖЕК, 2003. 328 с.

6. Семенов Г.А., Бугай В.3. Фінансове планування і управління на підприємствах: навч. посібник. К.: Центр учбової літератури, 2007. 432 с.

7. Федонін О.С., Репіна І.М. Потенціал підприємства: формування та оцінка: навч. посіб. К.: КНЕУ, 2004. 316 c.

8. Yarovaya N., Vorkunova O., Ryabovolenko N. Development and calculation of tariffs port works and services: зб. наук. пр. Дніпропетровський наи. універ. залізничного транспорту ім. акад. В. Лазаряна «Проблеми економіки транспорту». Вип. 12. Дніпро: Дніпропетр, 2016. С. 22-29. ISSN 2309-IX (Print) ISSN 2310-2438 (Online)

9. Yarovaya N.V., Vorkunova O.V., Khotyeyeva N.V. Economic assessment of the alternative energy sources implementation for port enterprises // Economic AnnalsXXI. 2017. Vol. 166, Issue 7-8, P. 46-50. DOI: https://doi.org/10.21003/ ea. V166-09

10. Яровая Н.В., Рябоволенко Н.В. Контроллинг как инструмент координации в принятии управленческих решений при ценообразовании // Розвиток методів управління та господарювання на транспорті: зб. наук. пращьь. Вип. 1(46). Одеca: OHMУ, 2014. C. 39-53.

11. Davydenko N.M. Genesis of enterprise financial security [Internet source]. Economic Processes Management: International Scientific E-Journal. 2015. № 2. URL: http://epm.fem.sumdu.edu.ua/download/2015_2/2015_2_3.pdf.

\section{REFERENCES}

1. Vorkunova, O.V., Khoteyeva, N.V., Makoveichuk, K.B. \& Pavilionita-Karpova K.S. Faktory` formuvannya efekty 'vnoyi sy`stemy`ekonomichnoyi bezpeky` pidpry`yemstv mors `koyi galuzi [Factors of formation of an effective system of economic safety of enterprises of the maritime industry]. Zbirny`k naukovy`x pracz`Dnipropetrovs ${ }^{`} y^{`} j$ nacional`ny`j universy`tet zalizny`chnogo transportu imeni akademika V. Lazaryana «Problemy`ekonomiky`transportu»-Collection of scientific works Dnipropetrovsk National University of Railway Transport named after Academician V. Lazaryan «Problems of Transport Economics», 13, 47-53 [in Ukrainian].

2. Kuprienko, S.V. (2008). Formuvannya programy` rozvy`tku materialo-texnichnoyi bazy` mors 'kogo torgovogo portu [Formation of the program of development of material and technical base of the sea commercial port]. Extended abstract of candidate's thesis. Odessa [in Ukrainian].

3. Onisko, S.M. \& Marich, P.M. (2005). Finansi pidpriyemstv [Business Finance]. Lviv: Magnoliya Plyus [in Ukrainian].

4. Oficijnyj veb-sajt Derzhavnoi' sluzhby statystyky [The official website of the State Statistics Service]. ukrstat.gov.ua. Retrieved from http://ukrstat.gov.ual [in Ukrainian].

5. Ponomarenko, V.S., Tridid, O.M. \& Kizim, M.O. (2003). Strategiya rozvitku pidpriyemstva $v$ umovah krizi [The strategy of enterprise development in a crisis]. Harkiv: INZhEK [in Ukrainian]. 
6. Semenov, G.A. \& Bugaj, V.Z. (2007). Finansove planuvannya i upravlinnya na pidpriyemstva [Financial Planning and Management for Enterprises]. Kiyiv: Centr uchbovoyi literature [in Ukrainian].

7. Fedonin, O.S. \& Ryepina I.M. (2004). Potencial pidpriyemstva: formuvannya ta ocinka [Enterprise potential: formation and evaluation]. Kiyiv: KNEU [in Ukrainian].

8. Yarovaya, N., Vorkunova, O. \& Ryabovolenko N. (2016). Development and calculation of tariffs port works and services. Zbirny`k naukovy`x pracz`Dnipropetrovs`ky`j nacional`ny`j universy`tet zalizny`chnogo transportu imeni akademika V. Lazaryana «Problemy`ekonomiky` transportu»-Collection of scientific works Dnipropetrovsk National University of Railway Transport named after Academician V. Lazaryan "Problems of Transport Economics», 12, 22-29.

9. Yarovaya, N.V., Vorkunova, O.V. \& Khotyeyeva, N.V. (2017). Economic assessment of the alternative energy sources implementation for port enterprises. Economic Annals-XXI. Vol. 166, Issue 7-8, 46-50. DOI: https://doi.org/10.21003/ea.V166-09

10. Yarovaya, N. \& Ryabovolenko, N. (2014). Kontrolling kak instrument koordinacii v prinyatii upravlencheskih reshenij pri cenoobrazovanii [Controlling as a tool for coordination in the decision-making of management decisions in pricing]. Rozvitok metodiv upravlinnya ta gospodaryuvannya na transporti - Development of methods of management and entrepreneurship on transport, 1(46), 39-53 [in Russian].

11. Davydenko, N.M. (2015). Genesis of enterprise financial security [Internet source] Economic Processes Management: International Scientific E-Journal. № 2. Retrieved from http://epm.fem.sumdu.edu.ua/ download/2015_2/2015_2_3.pdf.

Стаття надійшла до редакичї 20.01.2020

Посилання на статтю: Ярова Н.В., Воркунова О.В., Коцюбенко К.О., Ліщенко В.С. Формування методичних положень підвищення конкурентоспроможності контейнерного терміналу на прикладі «ТIC-контейнерний» // Розвиток методів управління та господарювання на транспорті: Зб. наук. праць, 2020. № 1 (70). C. 71-85. DOI 10.31375/22261915-2020-1-71-85.

Article received 20.01.2020

Reference a JournalArtic: Yarova, N.V., Vorkunova O.V., Kotsiubenko K.O. \& Lishchenko V.S. (2020). Formation of methodological provisions of increasing the competitiveness of the example TIS-container container terminal. Development of management and entrepreneurship methods on transport, 1 (70), 71-85. DOI 10.31375/2226-1915-2020-1-71-85. 